Endocrinol. Japon. 1985, 32 (4), 537-545

\title{
NOTE
}

\section{Pituitary Luteinizing Hormone Level in the Male House Musk Shrew, Suncus murinus L., Following Castration and Testosterone Treatment}

\author{
Keiko FURUMURA*, Katuaki ÔTA and Akira YOKOYAMA \\ Faculty of Agriculture, Nagoya University, Nagoya 464 \\ *Department of Dairy Science, Obihiro University of \\ Agriculture and Veterinary Medicine, Obihiro 080
}

\begin{abstract}
The effect of castration and replacement therapy with testosterone propionate (TP) on the pituitary LH concentration and contents in the house musk shrew was investigated by using an in vitro bioassay for $\mathrm{LH}$, the Rat Interstitial Cell Testosterone assay. The concentration and contents of LH increased slightly 10 days after castration, but decreased progressively thereafter to about a half of the pre-operation level by 90 days after the operation. The replacement with TP $(100 \mu \mathrm{g} /$ day $)$ for 7 days significantly depressed LH contents when it was begun 10 days after castration, while the same treatment started immediately after or 30 days after the operation did not significantly affect the pituitary LH level. The feedback mechanism between the gonad and the pituitary may be slightly different in the shrew from that in other mammals.

TP replacement, started immediatly after castration, completely inhibited the decrease in the weight of male accessory sex organs in castrated shrews. In castrated animals when more than 10 days had elapsed after the operation, however, the decreased weight of the organs could not be fully restored by the TP replacement for 7 days.
\end{abstract}

During the last few years we have investigated various reproductive traits in the house musk shrew, Suncus murinus L., a new laboratory animal of the insectivore (Furumura et al., 1982, 1983, 1984). A1though the concentration and contents of the steroid hormone either in the plasma or the tissues of the house musk shrew have been reported (Hasler et al., 1975; Hasler and Nalbandov, 1978; Furumura et al., 1983, 1984), information on the level of the peptide

Received December 14, 1984 hormones in this species have not yet been available. Since no cross reaction was found between the pituitary homogenates of the house musk shrew and the presently available anti-serum for luteinizing hormone (LH) (Wakabayashi, personal communication), a specific bioassay (Rat Interstitial Cell Testosterone assay, RICT assay; Dufau et al., 1974, 1976) was applied for the measurement of pituitary LH. The present study aimed at providing basic information on the pituitary LH level in the house musk shrew by elucidating the effects of castration and 
testosterone replacement on the level.

In the female shrew, ovariectomy or estrogen treatment affects neither uterine and vaginal histology nor sexual receptivity (Dryden and Anderson, 1977). Therefore, the effect of castration and testosterone replacement on the weight of the male accessory sex organs was also studied.

\section{Materials and Methods}

\begin{abstract}
Animals
The house musk shrew, brought from southern Japan (Furumura et al., 1983), has been maintained as a closed colony for over 10 generations. Adult male animals weighing $53-80 \mathrm{~g}$ ( 5 to 20 months old) were used in the present study. They were housed individually in polycarbonate cages $(18 \times 25 \times 13 \mathrm{~cm})$ and kept in a temperature $\left(20-30^{\circ} \mathrm{C}\right)$-and light $(14 \mathrm{~L}: 10 \mathrm{D}$, lights on $0500 \mathrm{~h})$ -controlled animal room. The commercial food pellets for young rainbow trout (3P: Chubu Shiryo Co., Ltd, Nagoya, Japan) and water were given ad libitum. A small amount of boiled egg or canned bonito flakes (CK : Oriental Kobo Kogyo K.K., Tokyo, Japan) was also given once a week.

Male rats (Wistar-Imamichi strain, Dobutsu Hanshoku Kenkyujo, Omiya, Japan) weighing $150-250 \mathrm{~g}$ were used as the donors of the testicular cells for the RICT assay.
\end{abstract}

Orchidectomy and testosterone replacement in the house musk shrew

The testes were removed under light ether anesthesia and the castrated animals were killed 10 (舍 10 group), 30 (类 30 group) or 90 (令 90 group) days after the operation. Adult male shrews over 9 months old served as the intact control (Intact group).

For the replacement experiment, another series of castrated animals were injected with $100 \mu \mathrm{g}$ of testosterone propionate (TP) in $0.1 \mathrm{ml}$ soybean oil or the same amount of vehicle s.c. daily for 7 days from the day of operation (0-TP, -Oil groups) or from 10 (10-TP, -Oil groups) or 30 days (30-TP, -Oil groups) after the operation. On the morning following the last injection, i.e. 8,18 and 38 days after castration, the animals were bled to death under ether anesthesia by heart puncture. Pituitary, adrenal and musk glands were removed and weighed. The pituitary gland was stored at $-20^{\circ} \mathrm{C}$ until used for $\mathrm{LH}$ assay. After the removal of the adrenal gland, the caudal half of the body trunk was fixed with $10 \%$ formalin for 18 to $20 \mathrm{hrs}$ and then seminal vesicles and ventral prostate glands were dissected out and weighed. Blood was centrifuged at $3,000 \mathrm{rpm}$ for $15 \mathrm{~min}$ at $4^{\circ} \mathrm{C}$ and plasma was stored at $-20^{\circ} \mathrm{C}$ for the testosterone measurement.

\section{Measurement of pituitary LH by RICT assay}

For each assay, testes from 2 male rats were used. Interstitial cells were isolated and prepared for RICT assay according to the method of Dufau et al. $(1974,1976)$. The cells from 4 testes were pooled and suspended in $10 \mathrm{ml}$ of Medium 199 containing 1\% bovine serum albumin (M199BSA ; pH 7.4), and incubated in a sealed glass vial for $60 \mathrm{~min}$ at $37^{\circ} \mathrm{C}$ under $95 \% \mathrm{O}_{2}-5 \% \mathrm{CO}_{2}$ gas phase with continuous shaking at 80 strokes/ min. After preincubation, the medium was renewed and viability of the cells were checked by trypan blue staining. Finally, the cells were suspended in M199-BSA at a density of $2.0 \times 10^{6}$ cells $/ \mathrm{ml}$ and used for the assay. Pituitaries from 2 shrews were pooled and assayed at one time. The glands stored at $-20^{\circ} \mathrm{C}$ were thawed, homogenized with M199 using a teflon pestle homogenizer under ice-cold conditions. The homogenate was let stand in ice for $30 \mathrm{~min}$ and then centrifuged at $3,000 \mathrm{rpm}$ for $20 \mathrm{~min}$ at $4^{\circ} \mathrm{C}$. The supernatant obtained was diluted with M199-BSA to the appropriate concentrations in each assay (125$500 \mu \mathrm{g}$ eq. of pituitary $/ \mathrm{ml}$ ). Ovine LH was dissolved in M199-BSA. Five dosage levels (3.75$60.0 \mathrm{ng} / \mathrm{ml}$ ) were prepared to make the standard curve.

The interstitial cells with the pituitary extract or the hormone was incubated at $37^{\circ} \mathrm{C}$ for $3 \mathrm{hrs}$ under $95 \% \mathrm{O}_{2}-5 \% \mathrm{CO}_{2}$ gas phase by using glass tubes $(15 \times 105 \mathrm{~mm})$. Each tube contained $0.5 \mathrm{ml}$ of the rat interstitial cell suspension and $0.5 \mathrm{ml}$ of the pituitary extract or LH solution. Tubes containing $0.5 \mathrm{ml}$ of the buffer medium, instead of the extract or the hormone solution, were prepared as the incubation control (Control). All assays were performed in quadruplicate. The incubation was ended by chilling the glass tubes in ice-cold water for $5 \mathrm{~min}$. The cell free supernatant was obtained by centrifuge at $1,000 \times \mathrm{G}$ for $10 \mathrm{~min}$ at $4^{\circ} \mathrm{C}$ and stored $-20^{\circ} \mathrm{C}$ until RIA for testosterone. 


\section{Radioimmunoassay for testosterone}

Testosterone was measured by RIA using the rabbit antiserum to testosterone- $11 \alpha$-succ-BSA. The incubation medium was used for the assay directry or after being diluted with $0.01 \mathrm{M}$ phosphate buffer saline $(\mathrm{pH} 7.0)$ at an appropriate rate (up to 30 times). The plasma testosterone was extracted by ether and then assayed.

\section{Hormones and other drugs}

Ovine LH (NIAMDD-LH-S-21) was supplied by the Hormone Distribution Committee, National Institute of Arthritis, Metabolic and Digestive Diseases (Bethesda, Maryland, USA). Bovine albumin was obtained from Reheis Chemical Co. (Phoenix, Arizona, USA). The rabbit antisera to testosterone-11 $\alpha$-succ-BSA and $[1,2$, $\left.6,7,{ }^{3} \mathrm{H}\right]$ testosterone $(98.8 \mathrm{Ci} / \mathrm{m} \mathrm{mol})$ were purchased from Teikoku Hormone Mfg. Co. (Kawasaki, Japan) and New England Nuclear (Boston, Massachusetts, USA), respectively.

\section{Calculations}

The range of doses giving a linear dose response curve for the oLH standard and samples, and the parallelism between curves for the standard and samples were determined by the method of Bliss (1952). The LH potency in samples was obtained by using 2 doses each of the standard and the sample according to the method of Borth (1960) for multiple design analysis. Duncan's multiple range test (Duncan, 1955) was used for the comparison of group means.

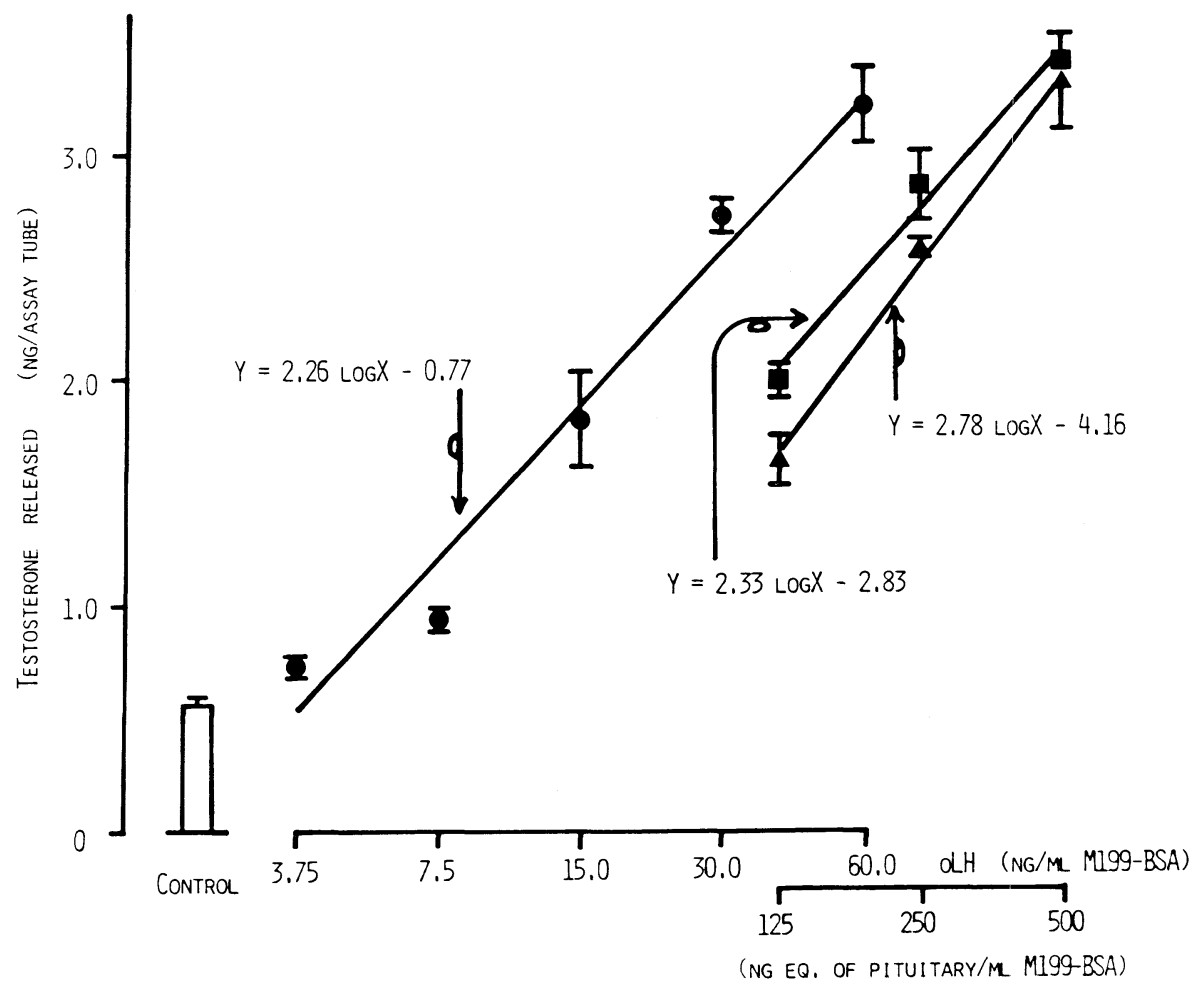

Fig. 1. Dose response curves of testosterone production in response to pituitary extracts of the house musk shrew and to oLH by the testicular interstitial cells of the rat cultured in vitro. The response is expressed in terms of amounts of testosterone released (ng/assay tube) during incubation for $3 \mathrm{hrs}$ with $1.0 \times 10^{6}$ cells/tube. $\Delta$ : Pituitary extract of the shrew 30 days after castration, $\mathbf{\square}$ : Pituitary extract of the shrew received testosterone propionate $(100 \mu \mathrm{g} / 0.1 \mathrm{ml}$ of soybean oil/day) for 7 days from 30 days after castration, 0 : oLH. Each point with vertical bars represents the mean \pm S.E.M. of quadruplicate estimations. 


\section{Results}

Application of RICT assay for the determination of pituitary LH of the house musk shrew

A standard curve for oLH was obtained over the range of doses from 3.75 to $60.0 \mathrm{ng} / \mathrm{ml}$ of M199-BSA. An eminent increase in testosterone production of the rat interstitial cell incubated in vitro was caused by adding the pituitary extract of the house musk shrew to the medium. The dose-response curves were linear over the range from 125 to $500 \mu \mathrm{g}$ eq. of pituitary/ $\mathrm{ml}$, roughly corresponding to $1 / 8$ and $1 / 2$ pituitary $/ \mathrm{ml}$, and no significant deviations from parallelism between the dose response curves obtained for oLH and the pituitary samples were observed in any assays. Typical samples are shown in Fig. 1, in which the regression equations for oLH and pituitary extracts of the castrated animal with or without TP replacement were $\mathrm{Y}=2.26 \log \mathrm{X}$ $-0.77(\lambda=0.11) . \quad \mathrm{Y}=2.78 \log \mathrm{X}-4.16(\lambda=$ $0.09)$ and $\mathrm{Y}=2.33 \log \mathrm{X}-2.83(\lambda=0.10)$, re- spectively, where $\mathrm{Y}$ is the amount of testosterone released per tube during the $3 \mathrm{hr}$ incubation period, $\mathrm{X}$ is the dose of ovine LH $(3.75-60.0 \mathrm{ng} / \mathrm{ml})$ or the pituitary extract $(125-500 \mu \mathrm{g}$ eq. of pituitary $/ \mathrm{ml})$ and $\lambda$ is the precision index of the dose-response line.

Effects of orchidectomy and testosterone replacement on the pituitary LH level in the shrew

The change in the concentration of pituitary $\mathrm{LH}$ with time after castration was very similar to that in the contents (Table 1). The concentration and contents had increased slightly by 10 days postcastration, though no significant difference in the values was obtained between the castrated and the intact control. A significant decrease in the concentrations and contents was observed at 30 and 90 days postcastration. The amounts of $\mathrm{LH}$ contained in the pituitary of $\$ 30$ and 590 were about $55 \%$ and $45 \%$ of those of the intact animals and $50 \%$ and $44 \%$ of those of the 10 , respectively.

Table 1. Effects of orchidectomy and testosterone replacement on the pituitary LH level in the house musk shrew. Castrated shrews were injected with testosterone propionate $(100 \mu \mathrm{g} / 0.1 \mathrm{ml}$ soybean oil/day) or vehicle $(0.1 \mathrm{ml}$ soybean oil/day) for 7 days from 0,10 or 30 days postoperation.

\begin{tabular}{|c|c|c|c|c|}
\hline \multirow{2}{*}{ Groups } & \multicolumn{2}{|c|}{ Days after castration } & \multicolumn{2}{|c|}{ Pituitary LH } \\
\hline & $\begin{array}{l}\text { Start of } \\
\text { injection }\end{array}$ & Autopsy & Concentration (ng/mg) & Content (ng/gland) \\
\hline Intact & - & - & $58.13 \pm 3.36^{\mathrm{a}, 1)}$ & $88.25 \pm 3.76^{\mathrm{ab}}$ \\
\hline \multicolumn{5}{|l|}{ Castration } \\
\hline 古 10 & - & 10 & $65.45 \pm 6.41^{\mathrm{a}}$ & $98.18 \pm 4.86^{a}$ \\
\hline 走30 & - & 30 & $31.83 \pm 5.97 \mathrm{~cd}$ & $50.68 \pm 5.77 \mathrm{de}$ \\
\hline 舍90 & - & 90 & $26.15 \pm 1.04 d$ & $42.78 \pm 4.06 \mathrm{e}$ \\
\hline \multicolumn{5}{|c|}{ TP-replacement } \\
\hline 0-Oil & 0 & 8 & $56.70 \pm 3.35 \mathrm{ab}$ & $82.35 \pm 6.54 \mathrm{abc}$ \\
\hline $0-\mathrm{TP}$ & 0 & 8 & $59.15 \pm 3.40^{\mathrm{a}}$ & $89.53 \pm 12.00^{\mathrm{ab}}$ \\
\hline 10-Oil & 10 & 18 & $56.73 \pm 4.51^{\mathrm{ab}}$ & $93.13 \pm 7.81^{\mathrm{a}}$ \\
\hline 10-TP & 10 & 18 & $44.10 \pm 5.78 \mathrm{bc}$ & $65.48 \pm 6.85^{\mathrm{cd}}$ \\
\hline 30-Oil & 30 & 38 & $31.80 \pm 1.38 \mathrm{~cd}$ & $58.08 \pm 1.73^{\mathrm{de}}$ \\
\hline 30-TP & 30 & 38 & $34.35 \pm 2.63 \mathrm{~cd}$ & $69.20 \pm 9.60^{\mathrm{bcd}}$ \\
\hline
\end{tabular}

1) Mean \pm S.E.M. of 4 determinations in each of which pituitaries of 2 animals were pooled.

$\mathrm{a}-\mathrm{d}$ : In Duncan's test no significant differences $(\mathrm{P}>0.05)$ were found between the values having the same superscript in each column. 


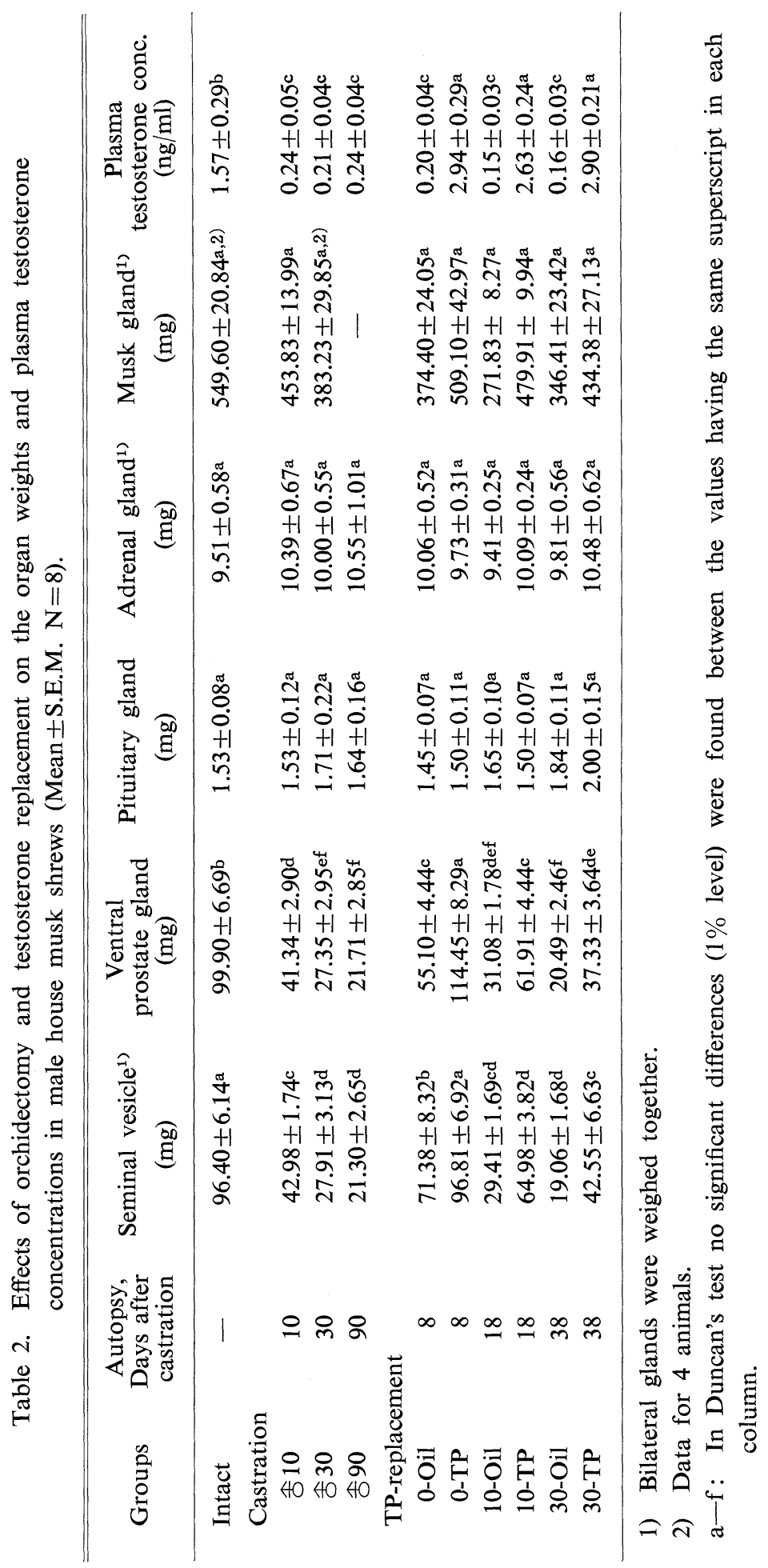


There were no significant differences in $\mathrm{LH}$ concentrations and contents among the intact, 0-TP and 0-Oil groups. TP administered from 10 days postcastration resulted in a significant decrease in the contents compared with that in the 10 -Oil or 510 groups. On the other hand, a slight increase, though not significant, was induced in the concentrations and contents compared with the 30 -Oil or 30 groups (Table 1) by the administration of TP from 30 days postcastration.

Effects of orchidectomy and testosterone replacement on the weight of male accessory sex organs and plasma testosterone concentration

Castration resulted in a significant decrease of the weight of male accessory sex organs (Table 2). Weights of both the seminal vesicle and the prostate gland at 10,30 and 90 days postcastration were $45 \%, 30 \%$ and $20 \%$ of the intact males, respectively. Plasma $\mathrm{T}$ concentration was depleted to about $15 \%$ of the level in the intact by 10 days after castration and this level was maintained thereafter.

Treatment with $100 \mu \mathrm{g} /$ day of TP for 7 days started from the day of operation effectively maintained the weight of the seminal vesicle and significantly increased the weight of the prostate gland compared with the weight in the intact group. Significant differences $(\mathrm{P}<0.01)$ between the weight of both organs in the TP treated animals and the vehicle injected control were obtained at 8 days after castration. Although TP administration from 10 or 30 days postcastration failed to restore the weight of the accessory sex organs to that of the intact males, the weight of the organs was definitely increased by the administration, compared with those of the corresponding controls. Plasma testosterone levels in the TP treated animals were about twice as high as those in the intact animals.

No significant differences were found in the weights of the pituitary and the adrenal gland among all experimental groups. The weight of the musk gland decreased after castration, though the pattern of change after 10 days of postcastration was not so obvious as that in the accessory sex organs.

\section{Discussion}

The RICT assay of Dufau et al., (1974, 1976) has been widely accepted as a reliable specific assay for LH. In parallel with the present series of experiments, we also proved that the addition of FSH or PRL, alone or together with $\mathrm{LH}$, into the incubation medium neither interfered nor augmented the in vitro testosterone production of the rat interstitial cells (Furumura et al., unpublished data). The assay has been used for the determination of LH not only in the pituitary gland of the human (Dufau et al., 1976), but also in the blood of the human (Dufau et al., 1976) and the monkey (Dufau et al., 1977). The present study clearly revealed that the assay could be successfully used for the measurement of $\mathrm{LH}$ in the pituitary of the shrew as well as the human, although the RICT assay was not applied for the determination of plasma $\mathrm{LH}$ in the house musk shrew.

The content and concentrations of the shrew pituitary LH increased slightly 10 days after castration. The increase, however, was only temporary and the pituitary level of LH decreased to about a half of that before the operation during the following 20 days. This pattern of change is quite different from that observed in the castrated rat, in which pituitary $\mathrm{LH}$ once decreased around 5 days postoperation, and increased rapidly until 2 weeks postcastration and then gradually thereafter (Badger et al., 1978; Clayton, 1981). If we assume that a negative feedback relationship between $\mathrm{LH}$ and testosterone secretions also exists in the house musk shrew as in other species, e.g. in the rat (Damassa et al., 1976) and the monkey 
(Plant, 1982), the results of the present study could be explained as follows: The slight increase in the $\mathrm{LH}$ content obtained 10 days after castration was due to an enhanced production of the hormone caused by the relief from the negative feedback of androgens. On the other hand, in the animals which spent a longer period after the operation, acceleration of the release of $\mathrm{LH}$ exceeded the rate of increase in the synthesis and then the amount of the hormone stored in the pituitary decreased. Replacement with TP strongly suppressed the production of LH in the initial stage of post-operation period, but had an even more profound effect on the release of the hormone in the later stage. This explanation is based on the assumptions that the balance of production and release of $\mathrm{LH}$ changes with time after castration and that the suppressing effects of testosterone on the production and the release vary in different states of pituitary function. It was demonstrated in the rat that the inhibitory effect of androgen on $\mathrm{LH}$ release was exerted at both the hypothalamic and pituitary levels (Ferland et al., 1976). Divergent effects of castration or TP replacement on the production and the release of LH at different stages of postcastration period would be probable.

Another plausible interpretation of the present result is the change in the number of LH producing cells in the pituitary of chronically castrated shrews. In the rabbit, Foster and Cameron (1964) observed histologically that gonadectomy induced a hyperplasia of the gonadotropic cells in the adenohypophysis immediately after the operation, but a pronounced reduction in the number of the cells occurred during the first month after castration and lasted for 4 months thereafter. This pattern of change seems to agree well with the change in the pituitary LH content in the present series of experiments, and the administration of TP might favor the survival and/or restoration of pituitary cells in the shrew.
Although the feedback effect of androgens on LH secretion is generally considered to be entirely negavive, there are several bodies of evidence suggesting the presence of positive effect in the rat (Swerdloff and Walsh, 1973; Verjans and Eik-Nes, 1977). Swerdloff and Walsh (1973) reported that the injection of low doses of TP $(30 \mu \mathrm{g} / 100 \mathrm{~g}$ body weight $\times 5$ days) resulted in an elevation of the serum level of LH in chronically castrated male rats. Thus, the positive feedback possibility deserves consideration in explaining the increase in the LH content caused by TP treatment in the shrew 30 days after castration. The feedback mechanism between pituitary and gonadal functions in the shrew may differ considerably from that in other mammalian species, although a final conclusion cannot be drawn until the blood levels of the hormone are determined.

The decrease in the weight of accessory sex organs in the castrated male shrews was completely prevented by the TP replacement started immediately after the operation. However, the weight loss of the organs could not be fully restored to the level in intact animals by the same treatment when the injection of TP was begun at a later time post operation. The plasma testosterone concentration in castrated animals treated with $100 \mu \mathrm{g}$ TP was about twice as high as that in intact animals. The dose of TP used in the present study, therefore, seemed to be enough to maintain the normal function of the accessory sex organs. A larger amount of the hormone or a longer period of treatment might be needed for restoration of the structure and the function of once degenerated organs as reported in the rat (Heller et al., 1943). In the female shrew, ovariectomy and estrogen replacement from 3 months after the operation did not induce any change in weight or histology in the uterus and the vagina (Dryden and Anderson, 1977). We also observed the lack of uterine response to estrogen $(1.0 \mu \mathrm{g}$ of estradiol $\times 15$ days) in the ovariectomized shrew, though 
the vaginal epithelium showed extensive proliferation (Tokuyama, unpublished). Such an unusual features in the response to gonadal steroid observed in the female uterus are not seen in the case of the male accessory sex organs.

Orchidectomy also decreased the weight of the musk gland and the treatment with TP restored weight considerably. Dryden and Conaway (1967) reported that the decrease in weight of the musk gland in the castrated shrew could be recovered by treatment with estradiol and progesterone as well as TP. Although the musk gland may not be a major scent gland in the species (Dryden and Conaway, 1967), the relation between the function of this gland and gonadal steroids might be studied.

\section{Acknowledgements}

We are grateful to the National Institute of Arthritis, Diabetes and Digestive and Kidney Diseases (NIADDK, Bethesda, Maryland, USA) for kindly supplying the ovine $\mathrm{LH}$ used in the present study. Our thanks are also due to Dr. K. Wakabayashi, Institute of Endocrinology, Gunma University, for testing the immunological cross reaction of the pituitary of the house musk shrew with rat LH, and to Dr. K. Tanaka and Dr. M. Kamiyoshi, Faculty of Agriculture, Gifu University, for their technical advice concerning the RICT assay. We also thank Mrs. Y. Niwa for her secretarial assistance.

\section{References}

Badger, T. M., C.E. Wilcox, E. R. Meyer, R. D. Bell and T. J. Cicero (1978). Simultaneous changes in tissue and serum levels of luteinizing hormone, follicle-stimulating hormone, and luteinizing hormone/follicle-stimulating hormone releasing factor after castration in the male rat. Endocrinology 102, 136-141.

Bliss, C. L. (1952). The statistics of bioassay. New York: Academic Press.

Borth, R. (1960). Simplified mathematics for multiple bioassay. Acta Endocrinol. (Kbh.) 35, 454-468.
Clayton, R. M. and K. J. Catt (1981). Regulation of pituitary gonadotropin-releasing hormone receptors by gonadal hormones. Endocrinology 108, 887-895.

Damassa, D. A., D. Kobashigawa, E. R. Smith and J. M. Davidson (1976). Negative feedback control of LH by testosterone: A quantitative study in male rats. Endocrinology 99, 736-742.

Dryden, G. L. and C. H. Conaway (1967). The origin and hormonal control of scent production in Suncus murinus. J. Mammal. 48, 420428.

Dryden, G. L. and J. N. Anderson (1977). Ovarian hormone: Lack of effect on reproductive structures of female Asian musk shrew. Science 197, 782-784.

Dufau, M. L., C. R. Mendelson and K. J. Catt (1974). A highly sensitive in vitro bioassay for luteinizing hormone and chorionic gonadotropin: Testosterone production by dispersed Leydig cells. J. Clin. Endocr. 39, 610-613.

Dufau, M. L., R. Pock, A. Neubauer and K. J. Catt (1976). In vitro bioassay of LH in human serum: The rat interstitial cell testosterone (RICT) assay. J. Clin. Endocr. 42, 958-969.

Dufau, M. L., G. D. Hodgen, A. L. Goodman and K. J. Catt (1977). Bioassay of circulating luteinizing hormone in the rhesus monkey: Comparison with radioimmunoassay during physiological changes. Endocrinology 100, 15571565.

Duncan, D. B. (1955). Multiple range and multiple F tests. Biometrics 11, 1-42.

Ferland, L., J. Drouin and F. Labrie (1975). Role of sex steroids on LH and FSH secretion in the rat. In: Current Topics in Molecular Endocrinology, Vol. 3, Hypothalamus and Endocrine Functions (F. Labrie, J. Meites and G. Pelletir eds.), Plenum Press, New York and London. pp. 191-209.

Foster, C. L. and E. Cameron (1964). Cytological changes in the adenohypophysis of the rabbit after castration. J. Endocrinol. 30, 97101.

Furumura, K., K. Ôta and A. Yokoyama (1982). Suncus murinus (the house musk shrew), In Mammalian Reproductive Physiology Aspects of its Animal Experimentation (Y. Suzuki ed.), ${ }_{\mathrm{S}}^{\mathrm{S} S o f t}$ Science Inc., Tokyo. pp. 404411. (In Japanese).

Furumura, K., K. Ôta, A. Yokoyama and S. Oda (1983). Mammary growth and plasma progesterone level during pregnancy in the house 
musk shrew, Suncus murinus LINNAEUS. Endocrinol. Japon. 30, 621-630.

Furumura, K., T. Kuriki and S. Miyazaki (1984). Growth and sexual maturation of the male house musk shrew (Suncus murinus). Exp. Animals. 33, 193-200. (In Japanese with English Summary).

Hasler, M. J., R. E. Falvo and A. V. Nalbandov (1975). Testosterone development and testosterone concentrations in the testis and plasma of young male shrews (Suncus murinus). Gen. and Comp. Endocrinol. 25, 36-41.

Haslar, M. J. and A. V. Nalbandov (1978). Pregnancy maintenance and progesterone concentrations in the musk shrew, Suncus murinus (Order; Insectivora). Biol. Repr. 19, 407-413.

Heller, C. G., A. Segaloff and W. O. Nelson (1943). Effect of testosterone replacement on the pituitary gonadotropic potency of the castrated male rat. Endocrinology 33, 186-188.

Keefer, D. A. and G. L. Dryden (1982). Nuclear uptake of radioactivity by cells of pituitary, brain, uterus, and vagina of the Asian musk shrew (Suncus murinus) following ${ }^{3} \mathrm{H}$ estradiol administration. Gen. Comp. Endocrinol. 47, 125130.

Plant, T. M. (1982). Effects of orchiectomy and testosterone replacement treatment on pulsatile luteinizing hormone secretion in the adult rhesus monkey (Macaca mulatta). Endocrinology 110, 1905-1013.

Swerdloff, R. S. and P. C. Walsh (1973). Testosterone and estradiol suppression of $\mathrm{LH}$ and FSH in adult male rats: Duration of castration, duration of treatment and combined treatment. Acta Endocrinol. (Kbh.) 73, 11-21.

Verjans, H. L. and K. B. Eik-Nes (1977). Comparison of effects of C 19 (androstene and androstane) steroids on serum gonadotrophin concentrations and on accessory reproductive organ weights in gonadectomized, adult male rats. Acta Endocrinol. (Kbh) 84, 829-841. 